\title{
PENGETAHUAN GURU TENTANG KONSEP WIRAUSAHA LITERASI DALAM PEMBELAJARAN BAHASA INDONESIA DI SMA
}

\author{
Keken Wulansari ${ }^{1}$, Sugit Zulianto ${ }^{2}$, Chafit Ulya ${ }^{3}$ \\ Universitas Sebelas Maret \\ Email:kekenw@student.uns.ac.id ${ }^{1}$,Sugit_Zulian@staff.uns.ac.id ${ }^{2}$, \\ Chafit@staff.uns.ac.id ${ }^{3}$
}

\begin{abstract}
Abstrak: Pembelajaran Bahasa Indonesia di sekolah merupakan pembelajaran berbasis teks produktif-apresiatif yang berpeluang bernilai wirausaha bagi siswa sehingga dibutuhkan bimbingan guru yang memiliki pengetahuan wirausaha literasi. Penelitian ini bertujuan untuk mengeksplorasi pengetahuan guru Bahasa Indonesia tentang kompetensi wirausaha. Penelitian ini merupakan penelitian deskriptif kuantitatif dengan pendekatan survei. Sumber data adalah guru Bahasa Indonesia di SMA Kota Surakarta. Teknik pengumpulan data dengan kuesioner tertutup menggunakan skala Linkert. Analisis data menggunakan statistik deskriptif dengan memerhatikan mean ideal dan standar deviasi ideal. Hasil penelitian ini menunjukkan bahwa aspek pengetahuan manajemen dan organisasi memiliki rerata persentase paling tinggi yaitu 35\% dengan jumlah skor 429. Disusul oleh aspek pengetahuan bidang usaha yang ditekuni dengan rerata presentase sebesar $34 \%$ dan memiliki jumlah skor 557. Aspek yang paling rendah adalah aspek pengetahuan peran dan tanggung jawab dengan rerata presentase sebesar $31 \%$ dengan jumlah skor 337 . Dengan demikian, dapat disimpulkan bahwa guru memiliki pengetahuan yang memadai mengenai manajemen dan organisasi, namun kurang mengatahui tentang peran dan tanggung jawab dalam berwirausaha sehingga perlu ditingkatkan melalui pelatihan.
\end{abstract}

Kata Kunci: dimensi pengetahuan, guru, pembelajaran, wirausaha literasi

\section{TEACHER KNOWLEDGE ABOUT THE CONCEPT OF LITERACY ENTREPRENEURS IN LEARNING INDONESIAN LANGUAGE IN SENIOR HIGH SCHOOL}

\begin{abstract}
Indonesian language learning in schools is a productive-appreciative text-based learning that has the opportunity to have entrepreneurial value for students so that the guidance of teachers who have entrepreneurial literacy knowledge are needed.. This study aims to explain the categories of knowledge about literacy entrepreneurial competencies that have been owned by Indonesian language teachers at SMA Kota Surakarta. This research is a quantitative descriptive study with a survey approach. The source of the data is the Indonesian language teacher at the Surakarta City Senior High School. The data collection technique was a closed questionnaire using the Linkert scale. The data validity technique uses content validity and Cronbach's Alpha reliability. Data analysis used descriptive statistics by taking into account the ideal mean and ideal standard deviation. The results of this study indicate that the knowledge aspect of management and organization has the highest average percentage of $35 \%$ with a total score of 429. Followed by the knowledge aspect of the field of business that is occupied with an average percentage of $34 \%$ and has a total score of 557. The lowest aspect is the knowledge aspect. roles and responsibilities with an average percentage of $31 \%$ with a total score of 337 . Thus, it can be concluded that teachers have adequate knowledge about management and organization,
\end{abstract}

BASASTRA Jurnal Bahasa, Sastra, dan Pengajarannya

Volume 9 Nomor 2, Oktober 2021, P-ISSN 2302-6405, E-ISSN 2714-9765 
but do not know about roles and responsibilities in entrepreneurship so they need to be improved through training.

Keywords: knowledge dimension, teacher, learning, literacy entrepreneur

\section{PENDAHULUAN}

Pembelajaran Bahasa Indonesia di sekolah merupakan pembelajaran produktif-apresiatif yang berbasis teks. Beberapa materi pembelajaran mengharuskan siswa untuk menghasilkan teks sesuai tuntutan KI KD dalam kurikulum. Kewajiban siswa untuk menghasilkan teks merupakan implementasi kemampuan siswa untuk dapat berpikir aras tinggi atau disebut juga dengan HOTS (Higher Order Thinking Skills). McMahon (dalam Tyas \& Naibaho, 2021: 177) menyebutkan bahwa model pembelajaran berbasis HOTS merupakan cara mempersiapkan siswa untuk turut bersaing dan berpartisipasi dalam era revolusi industri 4.0.

Mengelola pembelajaran berbasis HOTS yang produktifapresiatif dan melibatkan siswa untuk berpartisipasi memerlukan kompetensi guru yang mumpuni. Guru juga perlu memiliki pandangan yang visioner untuk dapat memanfaatkan hasil pembelajaran agar tidak hanya berhenti sebagai penugasan. Karya kebahasaan maupun sastra yang dihasilkan oleh siswa seperti cerita pendek, puisi, novel, dan lain sebagainya dapat dimanfaatkan menjadi produk karya unggulan yang bernilai guna. Hal tersebut dapat dilaksanakan dengan adanya komunikasi serta keakraban yang dapat dibangun oleh guru dan siswa (Widarmanto, 2013: 143).

Selain komunikasi, guru juga memerlukan pemahaman mengenai konsep wirausaha literasi dalam pembelajaran Bahasa Indonesia untuk memaksimalkan hasil karya dari siswa. Konsep wirausaha literasi secara sederhana dapat diartikan sebagai guru yang memiliki kemampuan menghasilkan produk baru serta dapat memasarkannya dengan menggunakan media bahasa (Suwandi, 2019: 68). Pembelajaran Bahasa Indonesia dapat dikelola dengan konsep wirausaha literasi dengan memanfaatkan hasil karya siswa yang sudah menjadi otoritas penuh milik siswa dan guru. Karya yang dihasilkan oleh siswa tidak hanya berhenti sebagai penugasan tetapi juga dapat menjadi produk karya yang bernilai guna. Karya sastra yang dapat dihasilkan oleh siswa seperti cerita pendek, puisi, novel, karya kerajinan berupa kaus, gantungan kunci yang memuat olah kata. Keterampilan lisan yang dapat dihasilkan seperti membaca puisi, mendongeng, dan lain sebagainya.

Keterampilan tersebut dapat diintegrasikan guru dengan pembelajaran Bahasa Indonesia yang memiliki kekhasan menarik karena mengajarkan empat keterampilan berbahasa yang meliputi menyimak, membaca, berbicara, dan menulis.

BASASTRA Jurnal Bahasa, Sastra, dan Pengajarannya 
Setiap keterampilan berbahasa dapat dijadikan pijakan untuk mendukung pengembangan industri kreatif (Syukron, 2017: 39). Sehingga hasil dari pembelajaran tidak hanya berhenti sebagai penugasan yang bermuara pada nilai tetapi dapat menjadi produk karya unggulan yang bernilai guna dan bernilai ekonomis.

Selanjutnya tugas guru adalah memilah dan memilih karya dari siswa serta mencari peluang di industri kreatif berbasis bahasa. Pembelajaran dengan konsep wirausaha literasi dapat diarahkan untuk menghasilkan luaran (outcame) yang mendukung industri kreatif di Indonesia. Adanya dukungan dari sistem pembelajaran yang telah dioptimalkan oleh guru dapat mengembangkan industri kreatif serta menginspirasi siswa untuk mengejar karir di bidang industri kreatif (Create, 2014: 10). Industri keratif berbasis bahasa dan sastra tidak hanya menghasilkan karya sastra tetapi juga karya kerajinan berbentuk kaus, topi, stiker, tas yang memuat olah kata di dalamnya. Olah kata yang dimaksud dapat berupa kata-kata motivasi, kata baku tidak baku, kutipan puisi, serta pantun (Hilaliyah \& Anam, 2017: 151).

Guru dapat mengarahkan siswa mencari peluang pada industri kreatif berbasis bahasa dengan memiliki pengetahuan tentang konsep wirausaha literasi. Pengetahuan guru tentang konsep wirausaha literasi merupakan kemampuan yang secara kreatif dan inovatif dengan ide dan gagasan yang dapat digunakan untuk menghasilkan menciptakan ide peluang usaha berbasis bahasa yang dapat menambah nilai guna bagi guru dan siswa. Bekal pengetahuan yang harus dimiliki guru dalam konsep wirausaha adalah bekal pengetahuan mengenai usaha yang akan dilakukan dan lingkungan usaha yang ada, pengetahuan tentang peran dan tanggung jawab, serta pengetahuan tentang manajemen dan organisasi bisnis (Rusdiana, 2018: 50).

Berbekal pengetahuan yang dimiliki serta keterampilan pengelolaan dan pemilihan strategi pembelajaran guru dapat Muttafaqur Rohmah dalam penelitiannya menyebutkan bahwa jika pembelajaran bahasa dan sastra akan lebih beragam serta mengarah pada karya yang dihasilkan oleh siswa dapat dimanfaatkan menjadi produk yang bernilai guna (Muttafaqur Rohmah, 2017). Berdasarkan pemaparan tersebut perlu dilakukan penelitian mengenai analisis dimensi pengetahuan guru tentang konsep wirausaha literasi dalam pembelajaran Bahasa Indonesia. Tujuan dari penelitain ini adalah menjelaskan mengenai kategori dari pengetahuan yang telah dimiliki oleh guru Bahasa Indonesia di SMA Kota Surakarta mengenai konsep wirausaha literasi sehingga guru dapat memaksimalkan kompetensi dari siswa dengan memanfaatkan hasil karya yang telah dibuatnya untuk menjadi produk yang bernilai guna. 


\section{METODE}

Penelitian ini menggunkan metode kuantitatif deskripfif dengan pendekatan survei. Menurut Singarimbun dan Effendi (dalam Sudaryo et al., 2019: 65) penelitian dengan alat pengumpul data utama berupa kuesioner serta mengambil sampel dari suatu populasi.

Populasi dari penelitian ini adalah seluruh guru Bahasa Indonesia di SMA negeri dan swasta di Kota Surakarta. Sampel atau responden dalam penelitian ini merupakan 40 orang guru Bahasa Indonesia di SMA Kota Surakarta yang diambil secara simple random sampling. Teknik pengambilan sampel dengan simple random sampling merupakan teknik yang dilakukan secara acak tanpa memerhatikan strata dari populasi (Sugiyono, 2013: 120).

Teknik pengumpulan data yang digunakan menggunakan kuesioner tertutup dengan menggunakan skala Linkert dengan empat alternatif jawaban. Teknik validitas data menggunakan pengujian validitas isi (contetnt validity). Validitas isi merupakan tes yang dilakukan untuk menguji kelayakan isi tes melalui analisis raisonal oleh expert judgement yang memastikan bahwa item tes sudah mewakili dan mengungkap konsep (Hendryadi, 2017: 171).

Reliabilitas yang digunakan pada penelitian ini menggunakan rumus alpha cronbach's $(\alpha)$. Instrumen pada penelitian ini menggunakan pilihan jawaban skala Likert 1 sampai
4 dengan pilihan jawaban sangat setuju, setuju, tidak setuju, dan sangat tidak setuju. Dimensi pengetahuan pada penelitian ini dikategorisasikan berdasarkan perhitungan deskriptif statistic untuk mengetahui mean (M), standar deviasi (SD), dan persentase (\%) hasil dari kuesioner.

\section{HASIL DAN PEMBAHASAN}

\section{Kategorisasi Pengetahuan Guru tentang Konsep Wirausaha literasi dalam Pembelajaran Bahasa Indonesia}

Penelitian ini menganalisis pengetahuan guru tentang konsep wirausaha literasi yang dikelompokkan secara berjenjang berdasarkan kategori yang sudah ditentukan. Terdapat tiga aspek dalam dimensi pengetahuan yang termuat dalam 10 pernyataan dalam kuesioner yang telah diisi oleh 40 orang responden guru Bahasa Indonesia di SMA Kota Surakarta. Data mengenai rerata, nilai tengah, nilai maksmimum, nilai minimum, range dan standar deviasi dari tanggapan responden dapat dilihat dalam tabel statistik deskriptif berikut ini:

Tabel 1. Statistik Deskripsi

\begin{tabular}{cc}
\hline \multicolumn{2}{c}{ Pengetahuan } \\
\hline Mean & 34 \\
Median & 34 \\
Min & 28 \\
Max & 30 \\
Range & 23 \\
Std. Deviation & 3,396 \\
\hline
\end{tabular}

Data diperoleh dari tanggapan responden pada angket dimensi pengetahuan tentang konsep wirausaha 
literasi. Data dianalisis dengan menggunakan program SPPS 23 sehingga diperoleh rerata (mean) sebesar 34, median sebesar 34, nilai terendah (minimum) sebesar 28, nilai tertinggi (maksimum) adalah 30, range adalah 23, serta standar deviasi sebesar 3,396.

Analisis mengenai dimensi pengetahuan konsep wirausaha literasi di SMA Kota Surakarta dilakukan dengan mempertimbangkan kedudukan skor terhadap mean ideal (Mi) dan standar deviasi ideal (SDi). Kategorisasi dimensi pengetahuan dibagi menjadi kategori sangat baik, baik, kurang baik, serta buruk. Tujuan kategorisasi adalah untuk mengelompokkan individu secara berjenjang dan terpisah menurut kontinum atribut yang diukur (Azwar, 12: 147). Hasil perhitungan kategorisasi dimensi pengetahuan guru dilihat pada tabel berikut ini.

Tabel 2. Perhitungan Normatif Kategori Dimensi Pengetahuan Guru

\begin{tabular}{cccc}
\hline Formula & Interval & skor & Kategori \\
\hline $\begin{array}{c}\mathbf{X} \geq \mathbf{M i}+\mathbf{1 , 5} \\
\mathbf{S D i}\end{array}$ & $\mathrm{X} \geq 32,5$ & $33-40$ & $\begin{array}{c}\text { Sangat } \\
\text { Baik }\end{array}$ \\
\hline $\begin{array}{c}\mathbf{M i}+\mathbf{1 , 5} \text { SDi } \\
>\mathbf{X} \geq \mathbf{M i}\end{array}$ & $\begin{array}{c}32,5>\mathrm{X} \\
\geq 25\end{array}$ & $25-32$ & Baik \\
\hline $\begin{array}{c}\mathbf{M i}>\mathbf{X} \geq \mathbf{M i} \\
\mathbf{- 1 , 5} \mathbf{S D i}\end{array}$ & $\begin{array}{c}25>\mathrm{X} \geq \\
17,5\end{array}$ & $18-24$ & $\begin{array}{c}\text { Kurang } \\
\text { Baik }\end{array}$ \\
\hline $\begin{array}{c}\mathbf{X}<\mathbf{M i} \mathbf{- 1 , 5} \\
\text { SDi }\end{array}$ & $\mathbf{X}<17,5$ & $10-17$ & Buruk \\
\hline
\end{tabular}

Skor kategorisasi pada dimensi pengetahuan guru dihitung dengan skor mean ideal yaitu sebesar 25 dan standar deviasi ideal sebesar 5. Kemudian diperoleh kategorisasi pada dimensi pengetahuan yang dibagi menjadi empat yaitu kategori sangat baik yang memiliki rentang skor 33-40, kategori baik memiliki rentang skor 2532, kategori kurang baik memiliki rentang skor 18-24, dan kategori buruk memiliki rentang skor 10-17. Diperoleh kategorisasi distribusi frekuensi dimensi pengetahuan guru sebagai berikut ini.

Tabel 3. Kategori Distribusi Frekuensi Dimensi Pengetahuan Guru

\begin{tabular}{cccc}
\hline Skor & Frekuensi & $\begin{array}{c}\text { Presen } \\
\text { tase }\end{array}$ & Kategori \\
\hline $33-40$ & 25 & $57,5 \%$ & $\begin{array}{c}\text { Sangat } \\
\text { Baik }\end{array}$ \\
\hline $25-32$ & 15 & $42,5 \%$ & Baik \\
\hline $18-24$ & 0 & $0 \%$ & $\begin{array}{c}\text { Kurang } \\
\text { Baik }\end{array}$ \\
\hline $10-17$ & 0 & $0 \%$ & Buruk \\
\hline Jumlah & 40 & $100 \%$ & \\
\hline
\end{tabular}

Tabel 3 menunjukan bahwa dari 40 orang responden terdapat 25 responden yang termasuk dalam kategori pengetahuan sangat baik, 15 responden termasuk dalam kategori pengetahuan baik, serta tidak terdapat responden yang memiliki kategori kurang baik maupun buruk. Presentase dari kategori pengetahuan guru yaitu $57,5 \%$ termasuk dalam kategori sangat baik dan $42,5 \%$ termasuk dalam kategori baik. Lebih dari $50 \%$ orang responden yaitu guru Bahasa Indonesia di SMA Kota Surakarta yang memiliki pengetahuan sangat baik serta tidak terdapat sama sekali guru yang memiliki pengetahuan buruk. 
Aspek-Aspek dalam Dimensi Pengetahuan Guru tentang Konsep Wirausaha Literasi.

Dimensi pengetahuan guru tetang konsep wirausaha literasi dalam pembelajaran Bahasa Indonesia terbagi menjadi tiga aspek. Aspek yang pertama yaitu pengetahuan manajemen dan organisasi, kemudian aspek pengetahuan bidang usaha yang ditekuni, serta aspek pengetahuan peran dan tanggung jawab. Aspekaspek dimensi pengetahuan tersebut termuat dalam kuesioner yang terdiri atas 10 pernyataan.

Tabel 4. Aspek-Aspek Dimensi Pengetahuan

\begin{tabular}{ccc}
\hline Aspek & $\begin{array}{c}\text { Jumlah } \\
\text { Skor }\end{array}$ & $\begin{array}{c}\text { Rerata } \\
\text { Persentase } \\
\text { \% }\end{array}$ \\
\hline $\begin{array}{c}\text { Pengetahuan manajemen } \\
\text { dan organisasi }\end{array}$ & 429 & $35 \%$ \\
\hline $\begin{array}{c}\text { Pengetahuan bidang } \\
\text { usaha yang ditekuni }\end{array}$ & 557 & $34 \%$ \\
\hline $\begin{array}{c}\text { Pengetahuan peran dan } \\
\text { tanggung jawab }\end{array}$ & 377 & $31 \%$ \\
\hline
\end{tabular}

Aspek pengetahuan manajemen

dan organisasi memiliki rerata persentase paling tinggi yaitu 35\% dengan jumlah skor 429. Disusul oleh aspek pengetahuan bidang usaha yang ditekuni dengan rerata presentase sebesar 34\% dan memiliki jumlah skor 557. Aspek yang paling rendah adalah aspek pengetahuan peran dan tanggung jawab dengan rerata presentase sebesar $31 \%$ dengan jumlah skor 337.

Aspek manajemen dan organisasi dalam dimensi pengetahuan memiliki persentase paling tinggi yaitu sebesar $35 \%$. Hal tersebut menggambarkan bahwa guru memiliki pengetahuan yang paling baik tentang konsep wirausaha literasi dalam aspek manajemen dan organisasi. Suwandi menjelaskan bahwa pembelajaran yang aktif, efektif, dan menyenangkan menuntut guru untuk menggunakan manajemen kelas atau strategi pembelajaran yang menyenangkan serta dapat turut aktif mengajak siswa berpartisipasi dalam pembelajaran (Suwandi, 2018: 7). Guru Bahasa Indonesia di SMA Kota Surakarta sudah memiliki pemahaman yang sangat baik serta harus menggunakan strategi yang baik dalam pengelolaan pembelajaran sehingga siswa dapat turut aktif berpartisipasi dalam menghasilkan karya yang dapat bernilai guna.

Aspek kedua yang paling tinggi dalam dimensi pengetahuan adalah pengetahuan mengenai bidang usaha yang ditekuni yaitu dengan presentase sebesar 34\%. Guru sudah memiliki pengetahuan yang baik tentang konsep wirausaha literasi dalam pembelajaran Bahasa Indonesia yang dapat diarahkan ke ranah produktif dengan memanfaatkan hasil karya siswa yang dapat menghasilkan nilai guna. Aspek yang memiliki presentase paling rendah dalam dimensi pengetahuan guru tentang kompetensi wirausaha literasi adalah pengetahuan mengenai peran dan tanggung jawab yang memiliki presentase sebesar $31 \%$. Guru sudah memiliki pengetahuan yang baik tentang konsep wirausaha literasi tetapi belum dimaksimalkan. Pengetahuan 
guru masih dalam ranah teoretis dan belum dilaksankan secara praktis dengan peran dan tanggung jawab.

\section{SIMPULAN}

Dimensi pengetahuan guru tentang konsep wirausaha literasi termasuk kategori sangat baik terutama dalam aspek manajemen dan organisasi. Dalam ketiga aspek dari dimensi pengetahuan yang belum dimaksimalkan oleh guru adalah aspek mengenai peran dan tanggung jawab. Guru di SMA Kota Surakarta sudah memiliki pengetahuan yang sangat baik mengenai konsep wirausaha literasi tetapi belum memaksimalkan peran dan tanggung jawab sebagai pendidik dengan pengimplementasian konsep tersebut dalam pembelajaran. Pengetahuan guru tentang kompetensi wirausaha literasi masih dalam ranah teoretis dan belum dilaksanakan secara praktis dengan maksimal. Penelitian ini dapat memberikan gambaran mengenai pengetahuan wirausaha literasi guru di SMA Kota Surakarta sehingga guru dapat mengimplementasikannya secara praktis dan bukan hanya sebatas konsep.

\section{REFERENSI}

Azwar, S. (2012). Penyusunan Skala Psikologi edisi 2. Pustaka Pelajar.

Create, U. (2014). Creative Industries Strategy. Print Opal.

Hendryadi. (2017). Validitas Isi: Tahap Awal Pengembangan Kuesioner. Jurnal Riset Manajemen Dan
Bisnis (JRMB) Fakultas Ekonomi UNIAT, 2 no 2, 169-179.

Hilaliyah, H., \& Anam, A. K. (2017). Alternatif Industri Kreatif Berbasis Bahasa dan Sastra Indonesia. Memajukan Kewirausahaan Dalam Upaya Membangun Indonesia.

Muttafaqur Rohmah. (2017). Geliat Industri Sastra di Sekolah: Pembelajaran Sastra Berbasis Industri Kreatif. Jurnal Bahasa Dan Sastra Indonesia Serta Pengajarannya, 3.

Rusdiana. (2018). Kewirausahaan Teori dan Praktik. CV Pustaka Setia.

Sudaryo, Y., Sofiati, N. A., Medidjati, R. A., \& Hadiana, A. (2019). Metode Penelitian Survei Online dengan Google Forms. Penerbit Andi.

Sugiyono. (2013). Metode Penelitian Kuantitatif, Kualitatif dan $R \& D$. Alfabeta.

Suwandi, S. (2019). Pendidikan Literasi. PT Remaja Rosdakarya.

Suwandi, S. (2018). Peran Guru Bahasa Indonesia dalam Penguatan Pendidikan Karakter Bagi Siswa. Seminar Nasional Pendidikan Bahasa Indonesia, 7.

Syukron, A. (2017). Arah Pengembangan Pembelajaran Bahasa dan Sastra Indonesia Berbasis Industri Kreatif dan Industri Budaya di Era Global. Bahasa Dan Sastra Dalam Konteks Global, 39.

Tyas, E. H., \& Naibaho, L. (2021). Hots Learning Model Improves the Quality of Education. International Journal of Research -GRANTHAALAYAH, 9(1), 177.

Widarmanto, T. (2013). Masa Depan

BASASTRA Jurnal Bahasa, Sastra, dan Pengajarannya

Volume 9 Nomor 2, Oktober 2021, P-ISSN 2302-6405, E-ISSN 2714-9765 
Sastra (Mozaik Telaah dan

Pengajaran

Sastra).

SatuKatabook@rt publishe. 